\title{
Deoxyribonucleate Binding and Transformation in Mycoplasma laidlawii
}

\author{
By C. E. FOLSOME \\ Department of Microbiology, University of Hawaii, \\ Honolulu, Hawaii
}

(Accepted for publication 30 June 1967)

SUMMARY

\begin{abstract}
Mycoplasmalaidlawii organismsarecapable of bindingin deoxyribonucleaseresistant form high molecular weight double- or single-stranded homologous or heterologous deoxyribonculeate in amounts of $0 \cdot \mathrm{I}-\mathrm{I} \cdot \mathrm{O} \times \mathrm{IO}^{-15} \mathrm{~g}$./organism, in a temperature-dependent mode. The maximum amounts of bound DNA ranged from 25 to 125 molecules of $5 \times 10^{6} \mathrm{~d}$. Transformation of streptomycinsensitive recipients to streptomycin resistance under conditions of maximum DNA uptake was relatively rare, being about 2-4-fold higher than spontaneous mutation. Ultraviolet (u.v.) inactivation studies showed that no caffeineinhibitable u.v. dark-repair mechanism was present. Photoreactivation was demonstrable; the PR cross-sector was 0.39 . From these results it was inferred that $M$. laidlawii is unable to be genetically transformed because of the absence of one or more steps which occur between irreversible DNA uptake and genetic integration. A model system which incorporates the above findings and suggests that donor DNA functions transiently in recipients is presented.
\end{abstract}

\section{INTRODUCTION}

Mycoplasma laidlawii organisms possess a circular single DNA molecule of $800 \times 10^{6} \mathrm{~d}$. (H. J. Morowitz, personal communication) and thus are at least three times less complex genetically than Escherichia coli $\left(2500 \times 10^{6} \mathrm{~d}\right.$.; Cairns, 1963). Conditional lethal mutants of $M$. laidlawii can be isolated with ease (Folsome \& Folsome, 1966). In general the organism, by virtue of its genetic simplicity and lack of metabolic versatility, seems to be an ideal subject for a complete genetic analysis ultimately directed towards saturation of the chromosome with conditional lethal mutant cistrons.

The present paper summarizes experiments upon deoxyribonucleate (DNA) binding, transformation, and ultraviolet radiation (u.v.) inactivation in Mycoplasma laidlawii. It shows that the organisms bound large amounts of DNA, that genetic transformation frequencies were very low, and that the organisms possessed no demonstrable caffeineinhibitable dark-repair mechanism. From these results it might be concluded that Mycoplasma laidlawii possesses no demonstrable recombination enzyme(s).

\section{METHODS}

Organisms. Mycoplasma laidlawii strain A, (ATCC 14089) was obtained from the American Type Culture Collection in 1965. This culture was passaged through ro subcultures before use: at each stage a typical single isolated colony was used as the inoculum. A spontaneous streptomycin-resistant mutant was isolated (resistant to at least $200 \mu \mathrm{g}$. streptomycin $/ \mathrm{ml}$.). 
Media. Tryptose (T) broth or agar plates containing, g./l. distilled water: 20 , Bacto-tryptose; 5, NaCl; 5, Na acetate; 5, tris; I, glucose; 10, (or 4 for soft agar) Davis New Zealand agar (when required), adjusted to $\mathrm{pH} 8.0$ with $6 \mathrm{~N}-\mathrm{HCl}$. Difco PPLO serum fraction was added to all sterile cooled media to a final concentration of $0.5 \%(\mathrm{v} / \mathrm{v})$. Streptomycin, at a final concentration of 50 or $10 \mu \mathrm{g} . / \mathrm{ml}$., was used as indicated below in soft agar overlays.

Colony-forming unit counts and transformant assays were done by suitably diluting and pipetting $0.01 \mathrm{ml}$. samples on to the surface of tryptose agar $(\mathrm{T})$ plates. After $4 \mathrm{hr}, \mathrm{I} \cdot 5 \mathrm{ml}$. soft agar streptomycin overlays were poured on $\mathrm{T}$ agar plates to select for str-r organisms. Plates were incubated $2-5$ days at $37^{\circ}$ and resultant colonies were counted with the aid of a Zeiss-Jena SMXX stereomicroscope at $\times 40$ magnification. The errors for this system of assays were not in excess of $8 \%$, as measured by computation of the standard deviation of many replicate assays.

DNA was isolated from I 1. Mycoplasma laidlawii or I 1. Escherichia coli exponential phase cultures according to the method of Marmur (1961).

$\left[2-{ }^{14} \mathrm{C}\right]$ Thymidine labelled $D N A$ was prepared from Escherichia coli $\mathrm{I}_{5} \mathrm{~T}^{-}$cultures grown in I 1. volumes of thymidine-supplemented minimal medium (after Strelzoff, I962) which contained 100 to $250 \mu \mathrm{c}$ of $\left[2-{ }^{14} \mathrm{C}\right]$ thymidine. $\left[2-{ }^{14} \mathrm{C}\right]$ Thymidine-labelled DNA was isolated from Mycoplasma laidlawii cultures grown in I 1 . volumes of Razin \& Cohen (1963) defined medium in which the thymidine concentration was decreased to ro $\mu \mathrm{g} . / \mathrm{ml}$. and to which was added $250 \mu \mathrm{c}$ of $\left[2-{ }^{14} \mathrm{C}\right]$ thymidine. The working specific activity of both labelled purified DNA preparations ranged from I 5,000 to 25,000 counts/min./extinction unit at $260 \mathrm{~m} \mu$ (one extinction unit equals $50 \mu \mathrm{g}$. native purified DNA.)

$\left[{ }^{14} \mathrm{C}\right] D N A$-binding studies. Volumes of up to $25 \mathrm{ml}$. of a reaction mixture of organisms and labelled DNA were filtered through a $0.22 \mu$ average pore size Millipore GS filter, treated as required, and washed with $30 \mathrm{ml}$. ice cold ultra-violet buffer. Ultra-violet buffer contained, per l. distilled water: tris $5 \mathrm{~g}$., $\mathrm{NaCl} 5 \mathrm{~g}$., $\mathrm{Na}$ acetate $5 \mathrm{~g}$., $\mathrm{MgSO}_{4} \cdot 7 \mathrm{H}_{2} \mathrm{O}$ $\mathrm{IO}^{-3} \mathrm{M}$, at $\mathrm{pH} 8 \cdot 0$. The extinction of this buffer was $0 \cdot 12$ at $2537 \AA$ and $10 \mathrm{~mm}$. path length. Organisms were essentially all retained on the surface of the filter. Air-dried filters were fastened to $\mathrm{I} \cdot 25$ in. planchets and the radioactivity measured with an ultra-thin window gas-flow Geiger detector using a Baird-Atomic model I 35 scaler. Background counts were IO-I I/min.; all count data presented here have been corrected for background.

Genetic transformation conditions were based upon the results of the DNA binding studies. Aerated $37^{\circ} \mathrm{T}$ broth exponential phase str-s recipient organisms were exposed to purified DNA isolated from str-r donors. DNAase and $\mathrm{MgCl}$ were added after $30 \mathrm{~min}$. to final concentrations of $\mathrm{IO}^{-}-50 \mu \mathrm{g} . / \mathrm{ml}$. and $\mathrm{IO}^{-3} \mathrm{M}$ respectively. Treated organisms, incubated for various times under non-selective conditions in $\mathrm{T}$ broth or on $\mathrm{T}$ plates, were then assayed for total colony-forming units on $\mathrm{T}$ agar plates, and for str-r transformants on streptomycin $10 \mu \mathrm{g}$. $/ \mathrm{ml}$. agar plates or on $\mathrm{T}$ agar on top of which was overlaid streptomycin soft agar overlays containing streptomycin to or $50 \mu \mathrm{g} . / \mathrm{ml}$. S plates were incubated at $37^{\circ}$ for $2-3$ days, then at $30^{\circ}$ for an additional 4 days. $T$ plates were incubated at $37^{\circ}$ for $2-3$ days.

Ultra-violet inactivation studies. These were done with Mycoplasma laidlawii or Escherichia coli under similar standard conditions: source, single $8 \mathrm{~W}$ General Electric germicidal low-pressure mercury lamp (G $8 \mathrm{~T} 5$ ); distance from material, $40 \mathrm{~cm}$. from 
lower edge of lamp tube; temperature, $20^{\circ} ;$ Mycoplasma laidlawii or Escherichia coli exponential phase cultures were diluted I/IO into u.v. buffer and irradiated with various doses in dim yellow light with agitation as $5 \mathrm{ml}$. volumes contained in the bottom of a $60 \times 10 \mathrm{~mm}$. sterile plastic Petri dish, covered until irradiation began with a Pyrex top coated with aluminium foil. Under these conditions a 2 I sec. u.v. dose corresponded to one lethal hit for Escherichia coli $\mathrm{F}^{-}(\lambda)^{\mathrm{s}}$ exponential phase organisms in u.v. buffer. Irradiated organisms were quickly diluted in $\mathrm{T}$ broth or caffeine-supplemented $\mathrm{T}$ broth (caffeine $0.75 \mathrm{mg} . / \mathrm{ml}$.) and immediately plated on to $\mathrm{T}$ or caffeine supplemented (0.75 mg./ml.) T agar plates. Both $\mathrm{T}$ and $\mathrm{T}$ caffeine (TC) agar plates were incubated at $30^{\circ}$ in light-tight boxes; a replicate $\mathrm{T}$ agar plate series was immediately exposed to two $\mathrm{I} 5 \mathrm{~W}$ daylight fluorescent lamps at a $20 \mathrm{~mm}$. distance for $4 \mathrm{hr}$ before incubation to permit photoreactivation (PR).

\section{RESULTS}

$D N A$ binding

Kinetic studies. Two $60 \mathrm{ml}$. exponential phase Mycoplasma laidlawii cultures were added to equal volumes of warmed $\mathrm{T}$ broth supplemented with $0.5 \%$ Difco yeast extract and incubated $30 \mathrm{~min}$. at $37^{\circ}$. To one culture was added $\left[{ }^{14} \mathrm{C}\right]$ Escherichia coli DNA (at a final concentration of $12 \mathrm{mg}$. $/ \mathrm{ml}$.), to the second $\left[{ }^{14} \mathrm{C}\right]$ Mycoplasma laidlawii DNA (at a final concentration of $\mathrm{I} 5 \mu \mathrm{g} . / \mathrm{ml}$.), and the mixtures incubated. Periodically Io $\mathrm{ml}$. volumes were withdrawn and filtered. At each time, and for each culture, two filter pads were prepared and washed; one pad was then exposed to and washed further in $10 \%$ trichloracetic acid at $4^{\circ}$ to precipitate nucleic acids. Figure I depicts the kinetics of binding of labelled DNA to intact organisms and to the TCA-precipitable fraction. These results indicate that the Mycoplasma laidlawii organisms bound homologous or heterologous DNA equally well. At $37^{\circ}$ binding occurred slowly; a plateau was reached by $30-40 \mathrm{~min}$. The amount of activity bound was the same for the intact-organism suspension or for the acid precipitable fraction and suggested that bound DNA was not extensively degraded; however, the label might have been degraded and re-incorporated. The maximum amount of DNA bound/ organism at $37^{\circ}$ was, for these experiments, about $30 \%$ of the organism's total haploid DNA content, or about $0.4 \times 10^{-15} \mathrm{~g}$. Many experiments of this type, with either homologously or heterologously labelled DNA, demonstrated that the maximum amount of DNA bound ranged from 0.2 to $1 \cdot 0 \times 10^{-15} \mathrm{~g}$./colony-forming unit. This range of bound DNA can be expressed as 25 to 125 molecules of size $5 \times 10^{6} \mathrm{~d}$., since both the general method of DNA extraction and related experiments made in our laboratory upon DNA-sucrose zone sedimentation indicated the molecular weight range of DNA preparations to be from 5 to $10 \times 10^{6} \mathrm{~d}$.

Temperature dependence. Standard volumes of exponential phase culture were mixed with Escherichia coli $\left[{ }^{14} \mathrm{C}\right]$ labelled DNA and incubated for $30 \mathrm{~min}$. at $4^{\circ}, 30^{\circ}$, $37^{\circ}, 40^{\circ}$. At the end of this time $4 \mathrm{ml}$. samples from each mixture were filtered, the filters washed and counted. Results are shown in Fig. 2. These results showed that DNA uptake was a temperature dependent process, possibly enzymic.

Permanent and transient binding of DNA. For this experiment a suspension of exponential phase organisms at $5 \times 10^{8} / \mathrm{ml}$. was mixed with Escherichia coli labelled DNA $\left(364 \mathrm{c} . / \mathrm{min} . / \mu \mathrm{g} ., 6 \mu \mathrm{g} . / \mathrm{ml}\right.$. final concentration) and incubated $30 \mathrm{~min}$. at $37^{\circ}$. 
Two $4 \mathrm{ml}$. volumes of culture were filtered. Ten $\mathrm{ml}$. of warmed u.v. buffer were added to the surface of one filter; ro ml. of u.v. buffer containing DNAase $50 \mu \mathrm{g} . / \mathrm{ml}$. in $10^{-3} \mathrm{M}-\mathrm{Mg}$ were added to the second filter. Both filters were incubated at $37^{\circ}$ for $20 \mathrm{~min}$. Then both filters were washed with chilled u.v. buffer, dried and counted.

Organisms upon both control and DNAase-treated filters possessed equal radioactivity $\left(725 \mathrm{c} . / \mathrm{min} . / 2 \times 10^{9}\right.$ colony-forming unit). This binding was equivalent to $8.3 \%$ of the total input label; the amount of DNA bound per colony forming unit was $1 \cdot 0 \times 10^{-15} \mathrm{~g}$. Apparently no detectable transient binding occurred; bound DNA

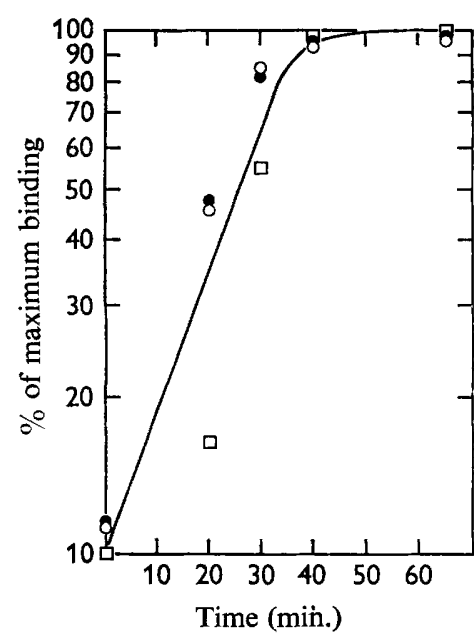

Fig. I

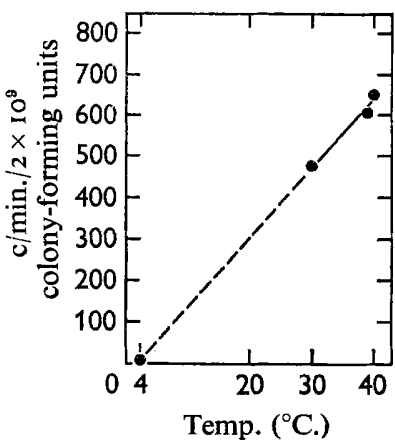

Fig. 2

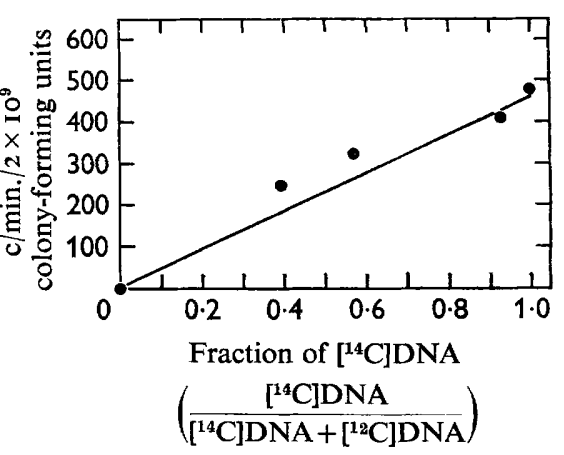

Fig. 3

Fig. I. The uptake of homologous or heterologous $\left[2-{ }^{14} \mathrm{C}\right]$-labelled DNA into intact Mycoplasma laidlawii A organisms or into cold acid precipitable fractions. Homologous labelled DNA: intact recipients at $3.7 \times 10^{8}$ colony-forming units $/ \mathrm{ml}$. were exposed to labelled DNA $12 \mu \mathrm{g} . / \mathrm{ml}$. of specific activity of $59 \mathrm{c} / \mathrm{min} . / \mu \mathrm{g}$. Maximum amount of label bound/organism after $40 \mathrm{~min}$. was $0.4 \mathrm{I} \times 10^{-9} \mu \mathrm{g}$. (O) intact organisms; $(O)$ acid precipitable fraction. Heterologous labelled DNA: $(\square)$ Recipient organisms at $3.7 \times 10^{8}$ colony-forming units $/ \mathrm{ml}$. were exposed to Escherichia coli labelled DNA at $15 \mu \mathrm{g} . / \mathrm{ml}$. and a specific activity of $375 \mathrm{c} / \mathrm{min} . / \mu \mathrm{g}$. Maximum amount of label bound/organism was $0.39 \times 10^{-9} \mu \mathrm{g}$.

Fig. 2. Temperature dependence of DNA binding by $M$. laidlawii A. Recipient organisms at $5 \times 10^{8} / \mathrm{ml}$. were exposed to $E$. coli $\left[{ }^{14} \mathrm{C}\right]$ DNA at $8.3 \mu \mathrm{g} . / \mathrm{ml}$. and a specific activity of $380 \mathrm{c} / \mathrm{min}$. $\mu \mathrm{g}$. at the temperatures indicated for a time of $30 \mathrm{~min}$. Then $4 \mathrm{ml}$. volumes were filtered and retained organisms washed, dried and counted.

Fig. 3. Competition between labelled and unlabelled DNA. $\left[{ }^{14} \mathrm{C}\right]$-labelled DNA at fixed amount $(15.8 \mu \mathrm{g} . / \mathrm{ml}$ ), various amounts of unlabelled DNA, and $5 \mathrm{ml}$. of suspension of $5 \times 10^{8} / \mathrm{ml}$. exponential phase $M$. laidlawii organisms were incubated $30 \mathrm{~min}$. at $37^{\circ}$. Then $4 \mathrm{ml}$. volumes were filtered, and the retained organisms washed, dried and counted.

was present in a form inaccessible to DNAase. However, weak interactions between DNA and organisms would not be observed by the above experiment because of the way in which the organisms were washed. Evidence for weak transient binding is discussed below.

Competition between $\left[{ }^{12} \mathrm{C}\right]$ and $\left[{ }^{14} \mathrm{C}\right]$ labelled DNA's. For this experiment exponential phase organisms $5 \times 10^{8} / \mathrm{ml}$. were exposed for a standard $30 \mathrm{~min}$. period at $37^{\circ}$ to 
mixtures containing a fixed amount of $\left[{ }^{14} \mathrm{C}\right]$ Escherichia coli DNA at $15 \cdot 8 \mu \mathrm{g} . / \mathrm{ml}$. and $380 \mathrm{c} . / \mathrm{min} . / \mu \mathrm{g}$., and variable amounts of unlabelled Escherichia coli DNA (from 0 to $26 \mu \mathrm{g}$. $/ \mathrm{ml}$.). The amounts of radioactivity retained per $4 \mathrm{ml}$. sample of filtered organisms were plotted against the fraction of radioactive DNA to give Fig. 3 . These results indicated that unlabelled DNA and $\left[{ }^{14} \mathrm{C}\right]$ DNA competed equally for binding to Mycoplasma laidlawii organisms. [ $\left.{ }^{14} \mathrm{C}\right] \mathrm{DNA}$ binding was decreased by $50 \%$ when equal concentrations of unlabelled DNA were present.

Binding of single-stranded DNA. One ml. Escherichia coli $\left[{ }^{14} \mathrm{C}\right] \mathrm{DNA}$ at $19 \mu \mathrm{g} . / \mathrm{ml}$. ( $360 \mathrm{c} . / \mathrm{min} . / \mu \mathrm{g}$.) was divided into two equal portions. One portion was heated I $5 \mathrm{~min}$. in a boiling water bath, then plunged into acetone ice for $5 \mathrm{~min}$.; this treatment, according to Doty, Marmur, Eigner \& Schildkraut (1960) thermally denatures DNA from double-stranded to single-stranded molecules. This treatment yielded a $25 \%$ hyperchromic shift in u.v. $(260 \mathrm{~m} \mu)$ extinction. Five $\mathrm{ml}$. volumes of exponential phase cultures at $5 \times 10^{8}$ colony-forming units $/ \mathrm{ml}$. were added to denatured and to native DNA's at $37^{\circ}$ for $30 \mathrm{~min}$. Four-ml. samples of these mixtures were filtered, washed and the radioactivity on the filter measured. Control (native) DNA-treated cultures bound $\mathrm{I} \cdot 14 \mu \mathrm{g}$. $\left(427 \mathrm{c} . / \mathrm{min} . / 2 \times 10^{9}\right.$ organisms), denatured DNA-treated suspensions bound $\mathrm{I} \cdot \mathrm{I} 2 \mu \mathrm{g}$. (403 c. $/ \mathrm{min} . / 2 \times 10^{9}$ organisms). One may conclude that Mycoplasma laidlawii bound native or denatured DNA equally well under the same conditions, and for $30 \mathrm{~min}$. exposure. Kinetic studies upon single-stranded DNA binding were not done; it is not possible to conclude that the uptake of both molecular species occurred with the same rate.

Dependence on high molecular weight DNA for binding. $\left[{ }^{14} C\right]$ Escherichia coli DNA at $\mathrm{I} 70 \mu \mathrm{g} . / \mathrm{ml}$. $(6 \mathrm{I}, 370 \mathrm{c} . / \mathrm{min}$. $/ \mathrm{ml}$.) was subjected to strong shearing forces in a Waring blendor at $4^{\circ}$ under $\mathrm{N}_{2}$ gas for various lengths of time. One ml. samples of sheared DNA were removed, mixed with $4 \mathrm{ml}$. recipient culture at $5 \times 10^{8}$ organisms $/ \mathrm{ml}$, incubated $30 \mathrm{~min}$. at $37^{\circ} ; 4 \mathrm{ml}$. were filtered, washed, and radioactivity measured. Figure 4 shows the results, which indicate that maximal DNA binding required high molecular weight DNA. Binding was decreased sixfold with a blending time as short as $\mathrm{I} \cdot 5 \mathrm{~min}$.

Concentration effect. $\left[{ }^{14} \mathrm{C}\right]$ Escherichia coli DNA (specific activity $370 \mathrm{c} . / \mathrm{min} . / \mu \mathrm{g}$. ; final concentrations from 12 to $0.12 \mu \mathrm{g} . / \mathrm{ml}$.) was added to recipients at $5 \times 10^{8}$ organisms $/ \mathrm{ml}$. After $30 \mathrm{~min}$. $37^{\circ}$ incubation 4 to $25 \mathrm{ml}$. samples were taken from each reaction mixture. The results are plotted in Fig. 5 as log fraction of input label bound against $\log$ concentration of $\mathrm{DNA} / \mathrm{ml}$. reaction mixture. The slope of the line is -0.43 . Hence the relative amount of DNA bound per organism was greater at higher DNA concentrations and lower at lower DNA concentrations. The amount of DNA bound varied exponentially with DNA concentration, but not proportionately. These data suggest that weak transient binding of DNA did occur and that effective contacts between organisms and DNA molecules occurred with exponentially greater probability at higher than at lower DNA concentrations.

Control experiments. Numerous control experiments were used to test the reproducibility and accuracy of the millipore filter method of collecting and washing recipient organisms. $\left[{ }^{14} \mathrm{C}\right]$ labelled DNA alone at concentrations from $10 \mu \mathrm{g}$. to $300 \mu \mathrm{g} . / \mathrm{ml}$. (specific activity $420 \mathrm{c} . / \mathrm{min} . / \mu \mathrm{g}$.) was passed through a millipore GS filter. After washing with u.v. buffer, no radioactivity exceeding background values was detectable. Recipient organisms at known titre were filtered and the filtrate 
assayed directly for colony forming units to determine whether any organisms would pass through the filter; no colonies (fewer than $\mathrm{I} / \mathrm{10}^{7}$ ) were detected. Thus the filtration and washing procedure as used here retained essentially all viable organisms and there was no non-specific retention of DNA to the filter. Samples of thermally denatured DNA were not retained upon the filter.

\section{Transformation}

The data obtained from transformation experiments are summarized in Table I. Clearly, transformation to str-r did seem to occur; but only with great rarity, since transformants were only about 2-4 times more frequent than spontaneous mutation to str-r. Control experiments in which no str-r DNA was present (Expt. I), or in

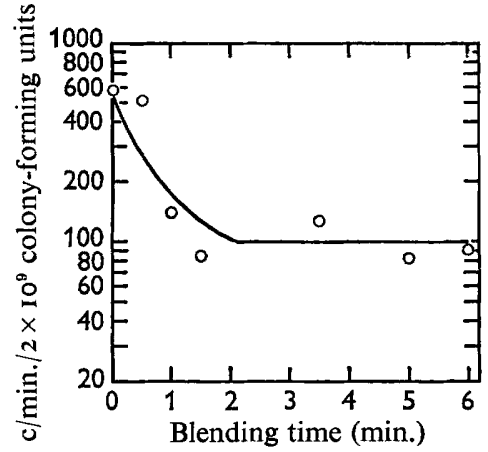

Fig. 4

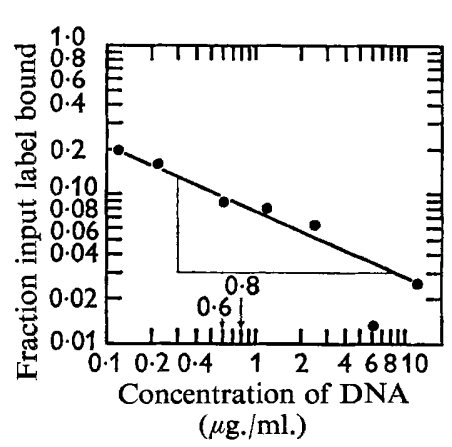

Fig. 5

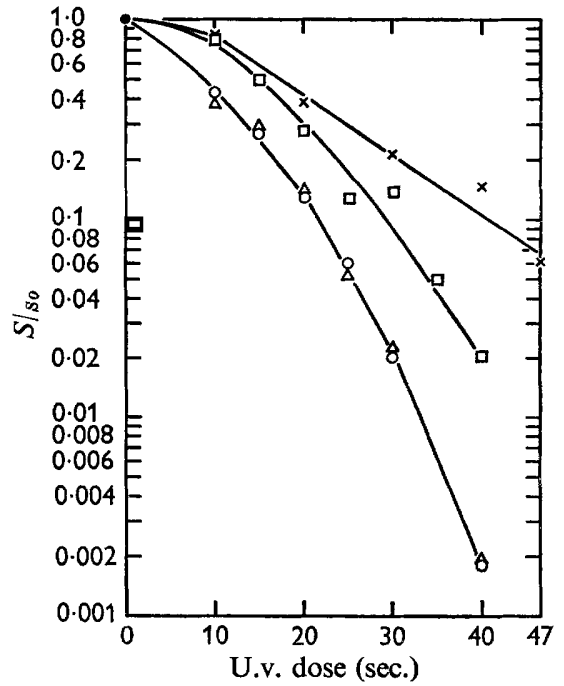

Fig. 6

Fig. 4. DNA binding dependence on high molecular weight. Labelled DNA was blended at $4^{\circ}$ under $\mathrm{N}_{2}$ for various times, removed, mixed with recipient organisms of $M$. laidlawii for $30 \mathrm{~min}$. at $37^{\circ}$, and the organisms then filtered, washed, dried and counted.

Fig. 5. Effect of DNA concentration. Log of input DNA concentration against log of fraction of input label bound.

Fig. 6. Ultraviolet inactivation of $M$. laidlawii A. Log-frequency survivors plotted against u.v.-dose for $M$. laidlawii incubated $(O)$ in dark at $30^{\circ},(\triangle)$ in dark on caffeine $\mathrm{T}$ agar at $30^{\circ}$, ( $\square$ ) exposed $4 \mathrm{hr}$ to light for photoreactivation. E. coli $\mathrm{K}-\mathrm{I} 2 \mathrm{~F}-(\lambda)^{-}$dark survival is also depicted ( $\times)$. M. laidlawii organisms were filtered through a $0.65 \mu$ Millipore filter to remove clumps before u.v.-irradiation.

which str-r DNA was first exposed to DNAase (Expt. IV) indicated that the increased frequency of $s t r-r$ colonies was specifically due to $s t r-r$ donor DNA and not to a less specific effect of DNA upon recipient organisms.

About 120 transformation experiments have been made following protocols similar to those of Table I. Three of these experiments showed transformation frequencies of $10^{-4}$ when control str-r colony frequencies were as low as $10^{-7}$. However, two other experiments of this group showed the converse results; control str-r frequencies of 
$\mathrm{IO}^{-4}$ to $1 \mathrm{I}^{-5}$ and str-r DNA recipient frequencies of $1 \mathrm{O}^{-6}$ to $\mathrm{IO}^{-7}$. Hence, the possibility does exist, although slight, that genetic transformation can occur, provided the correct combinations of elusive experimental parameters are present. A more probable explanation of the data is: (I) that true genetic transformation does not usually occur; (2) that the commonly observed low level of transformants is due to some other process (see below); (3) that the occasionaly high values for 'transformants' observed are due to the random occurrence of 'jackpots' of str-r mutants descendant from an early spontaneous str-r mutant in either str-r DNA-exposed or control cultures.

\section{Table I. Genetic transformation of Mycoplasma laidlawii A}

For all experiments reported in this table str-s recipient exponential phase organisms at $5 \times 10^{8}$ to $\mathrm{I} \times 10^{9}$ colony-forming units $/ \mathrm{ml}$. were exposed to DNA for $30 \mathrm{~min}$. at $37^{\circ}$; DNAase $\left(50 \mu \mathrm{g} . / \mathrm{ml}\right.$.) and $\mathrm{MgSO}_{4} \cdot 7 \mathrm{H}_{2} \mathrm{O}\left(\right.$ to $\left.\mathrm{IO}^{-3} \mathrm{M}\right)$ were added, and the mixture was either (a) diluted and pipetted onto $\mathrm{T}$ agar, incubated at $37^{\circ} \mathrm{C}$ for $4 \mathrm{hr}$, then overlaid with $\mathrm{I} \mathrm{ml}$. streptomycin soft $\mathrm{T}$ agar (Streptomycin $50 \mu \mathrm{g} . / \mathrm{ml}$.) and incubated at $37^{\circ}$ for 3-4 days, or (b) the broth mixture was incubated a further $100 \mathrm{~min}$. at $37^{\circ}$, and then pipetted on to streptomycin $10 \mu \mathrm{g} . / \mathrm{ml}$. T agar plates and incubated for $3-4$ days at $37^{\circ}$.

\section{Experiment}

I. $s t r-s$ recipients exposed under standard conditions. DNAase treated organisms plated on $\mathrm{T}$ agar and overlaid with streptomycin (50 $\mu \mathrm{g} . / \mathrm{ml}$.) soft agar after $4 \mathrm{hr}$

II. str-s recipients as Expt. I

III. $s t r-s$ recipients exposed under standard conditions, then incubated in broth Ioo min. and plated on to streptomycin (10 $\mu \mathrm{g} . / \mathrm{ml}$.) $\mathrm{T}$ agar plates

IV. Repeat of Expt. III, organisms plated on streptomycin (10 $\mu \mathrm{g} . / \mathrm{ml}$.) $\mathrm{T}$ agar plates

V. Repeat of Expt. III

\section{Donor DNA conc. and source}

Control, no DNA

Control, str-s DNA $8 \mu \mathrm{g} . / \mathrm{ml}$.

$s t r-r$ DNA Io $\mu \mathrm{g} . / \mathrm{ml}$.

str-r DNA $5 \mu \mathrm{g} . / \mathrm{ml}$.

$s t r-r$ DNA $0 \cdot \mathbf{I} \mu \mathrm{g} . / \mathrm{ml}$.

Control, no DNA

$s t r-r$ DNA $20 \mu \mathrm{g} . / \mathrm{ml}$.

$s t r-r$ DNA $5 \mu \mathrm{g} . / \mathrm{ml}$.

Control, no DNA

$s t r-r$ DNA $5 \mu \mathrm{g} . / \mathrm{ml}$

$s t r-r$ DNA $5 \mu \mathrm{g} . / \mathrm{ml}$. (duplicate)

Control, DNAase + str $r$ DNA $6 \mu \mathrm{g} . / \mathrm{ml}$

Control, no DNA

str-r DNA $6 \mu \mathrm{g} . / \mathrm{ml}$.

Control, no DNA

$s t r-r$ DNA $4 \mu \mathrm{g} . / \mathrm{ml}$. Frequency of exptl./
str- $r$ colonies control

$\begin{array}{lr}4.9 \times 10^{-7} & - \\ 5.0 \times 10^{-7} & - \\ 2.1 \times 10^{-6} & 4.2 \\ 1.5 \times 10^{-6} & 3.0 \\ 6.6 \times 10^{-6} & 13.2\end{array}$

$\begin{array}{ll}1 \cdot 7 \times 10^{-7} & - \\ 3.2 \times 10^{-7} & 1 \cdot 9 \\ 3.0 \times 10^{-7} & 1 \cdot 8 \\ 5.9 \times 10^{-5} & - \\ 1.1 \times 10^{-4} & \mathrm{I} \cdot 9 \\ 2.0 \times 10^{-4} & 3 \cdot 4\end{array}$

$3 \cdot 4$

None of the experiments reported here has ruled out the distinct possibility that the transformants to str-r might have arisen by some means other than recombination between donor str- $r$ DNA and recipient $s t r-r$ chromosome. For example, the observed increase in str-r transformants might have been due directly to spontaneous mutation occurring at normal frequencies in recipient organisms which were permitted (as a result of incorporation of str-r DNA) to undergo additional partial growth on streptomycin agar plates. Such an occurrence could generate data similar to those presented in Table I. Functional transformation has been observed to occur for pneumococcus by Evans (1964), has been discussed by Folsome (1964), and does appear to exist in Mycoplasma laidlawii (T. H. Iha \& Folsome, I966, unpublished experiments). 
In addition to the experiments recorded in Table $\mathrm{I}$, many other experiments have been made in which the effects of: $(a)$ culture age from early exponential to early stationary phase, $(b) \mathrm{pH}$ value from $6 \cdot 0$ to $9 \cdot 0,(c)$ presence or absence of $\mathrm{Mg}^{2+}$ and/or $\mathrm{Ca}^{2+},(d)$ temperature from $25^{\circ}$ to $40^{\circ},(e)$ various defined media, $(f)$ aerated or $\mathrm{N}_{2}$ gassed recipients, $(g)$ u.v.-irradiation of recipients to $0 \cdot 20$ survivors have been assessed. In these experiments, without exception, transformation frequencies were not increased. The conditions for optimal transformation thus far are those summarized in Table $I$. Concurrently with the above experiments, a search for other modes of genetic exchange was made: a str-r strain was cultured with a chloramphenicol resistant (chl-r) strain; at various times samples were spread on chloramphenicol streptomycin agar plates in an effort to detect double recombinant, chl-r str-r, colonies. The results of over I 5 of these experiments were uniformly negative.

Table 2. Ultraviolet (u.v.) sensitivities of Mycoplasma laidlawii A under various post-u.v.-irradiation conditions, and of Escherichia coli

$\begin{array}{clc}\text { Organism } & \text { Post-u.v.-condition } & \begin{array}{c}\text { Inactivation rate at } \\ \text { asymptote }(-d S / d D)\end{array} \\ M . \text { laidlawii A } & \text { Dark } & -2 \cdot 27 \\ & \text { Dark plus caffeine } & -2 \cdot 27 \\ \text { E. coli } \mathrm{K}-\mathrm{I} 2^{-\mathrm{F}}(\lambda)^{-} & \text {Photoreactivation } & -\mathbf{I} \cdot 39 \\ & \text { Dark } & -0.53\end{array}$

PR cross sector (Dulbecco, 1954) $=a$, where $a+b=1$, and $b=-d S / d D^{(\mathrm{PR})} /-d S / d D^{(\text {Dark })}=$ $-\mathrm{I} \cdot 39 /-2 \cdot 27=0.6 \mathrm{I}, a=0.39$.

\section{Inactivation by ultraviolet irradiation}

Survival of Mycoplasma laidlawii as a function of u.v. dose under three post-irradiation conditions was measured; the results are shown in Fig. 6. The three post-u.v. conditions were $(a)$ dark incubation on T agar plates, $(b)$ dark incubation upon TC caffeine $750 \mu \mathrm{g} . / \mathrm{ml}$. agar plates, $(c)$ immediate exposure of $\mathrm{T}$ agar plates to light for $4 \mathrm{hr}$ for photoreactivation (PR).

There was evidence: (I) for extreme u.v.-sensitivity of Mycoplasma laidlawii, (2) that no caffeine-inhibitable dark reactivation appeared to exist (see Metzger, 1964), (3) that PR could be clearly demonstrated (see Table 2). The PR cross-sector (Dulbecco, I950) was 0.39 (see Table 2 for mode of calculation). This value means that 0.39 of the u.v. lesions at asymptote were capable of photoreactivation. As comparison one might note that coli-phages possess PR cross-sectors ranging from 0.2 for

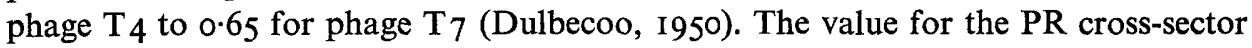
reported here for Mycoplasma laidlawii $(0.39)$ is a minimal one, since the PR light exposure may or may not have been maximal.

Notable was the extreme u.v.-sensitivity of Mycoplasma laidlawii as compared to Escherichia coli: the ratio of inactivation rates at asymptote was $4.3(-2 \cdot 27)-0.53$, see Table 2). If one normalizes the u.v.-sensitivities of these two organisms to a sensitivity per unit DNA, then Mycoplasma laidlawii was actually $4 \cdot 3 \times \sim 3$ ) $=13$ times more sensitive. Although this relative sensitivity might be the result of other unknown processes it is consistent with the postulate that Mycoplasma laidlawii possesses no u.v. dark reactivation mechanism. Most interesting, however, was the evidence for the lack of caffeine-inhibitable dark repair mechanism. With regard to this charac- 
teristic, Mycoplasma laidlawii appears to be similar to host-cell-reactivationless (HCR-) mutants of Escherichia coli (Sauerbier, 1964) and to u.v.-sensitive mutants of Escherichia coli K-I2 (Howard-Flanders \& Theriot, 1966). Also, transformable Bacillus subtilis does show a caffeine-inhibitable DR mechanism (Metzger, 1964).

\section{DISCUSSION}

Mycoplasma laidlawii organisms were capable of binding high molecular weight single-stranded or double-stranded DNA to a maximum amount of 0.1 to 0.2 of the organism's genomic DNA content within $30 \mathrm{~min}$. and in a temperature-dependent manner. Bound DNA appeared to remain as high molecular weight material for at least $60 \mathrm{~min}$., as shown by its acid precipitability. One must not discount the possibility that bound DNA was degraded and re-incorporated into newly synthesized recipient DNA.

The comparatively long period required for DNA binding ( $30 \mathrm{~min}$.) and the apparent DNA exponential concentration-dependence suggested by the results in Fig. 5 can be explained by postulating that concentration-dependent transient binding of DNA occurred within very short time intervals, and that actual DNA entry into the cell required the longer times observed here. The nature of this transient binding must be such that transiently bound DNA is washed off the organisms by the methods used for washing the filter pads. Thus, the experiments on DNA binding were not optimally designed to detect weak transient binding and served mainly to indicate that, once firmly bound, DNA was inaccessible to DNAase and was either within the organism or was held on its surface in a configuration resistant to DNAase attack.

Mycoplasma laidlawii binding of single-stranded DNA also occurred; thus this system, excluding competence, appeared in many ways similar to Hemophilus influenzae (Barnhart \& Herriott, 1963; Postel \& Goodgal, 1966). Although the same amount of ${ }^{14} \mathrm{C}$ label was bound for both native and denatured DNA at $30 \mathrm{~min}$., no kinetic data were available. As a consequence, one cannot state whether similar or different binding rates apply.

One can summarize the stages of DNA binding by listing this most probable sequence of events: (I) transient and quick binding of DNA by weak forces, (2) permanent binding requiring an enzymic mechanism, essentially complete by $30 \mathrm{~min}$. Implicit in the above sequence is the inference that the culture is uniformly competent at least by step 2 and that competence is the normal state of exponential phase cultures, or that transient binding induces competence.

In light of the ability of Mycoplasma laidlawii to bind DNA, the experiments on genetic transformation were most surprising since, except for spurious instances, 'transformant' frequencies of only 2-4 times higher than spontaneous mutation were recorded. Two possibilities may be considered: (I) DNA cannot penetrate the organism, but is bound to the surface in a nuclease resistant configuration; (2) DNA can enter the organism, but except for rare instances cannot be genetically recombined into the genophore due to absence of a recombination mechanism. In the event that DNA could not penetrate, one would not expect to observe even the low level of transformants reported. Since the slight transformation which did occur was the specific result of str-r DNA, non-penetration could only account for the results if a small subfraction of the population bound DNA internally, and a large fraction 
bound DNA in a DNAase resistant form externally. Several experiments on the survival of str-r recipients which had bound str-r DNA in streptomycin broth have indicated that bound DNA can function (Folsome, unpublished). Thus, for purposes of this discussion, it will be assumed that most bound DNA was internally located.

Were DNA to enter the cell, the question remains as to why transformant frequencies were str- $r$ DNA-specific, yet low. The model which best accounts for the result is as follows: (a) Within short spans of time, DNA transiently and weakly binds to the surface of recipient organisms. (b) Recipients normally possess an enzymic mechanism by which exogenous DNA can enter. $(c)$ Once within the organism, the ultimate fate of donor DNA is to be degraded, since Mycoplasma laidlawii requires all nucleosides in defined media (Tourtellotte, Morowitz \& Kasimer, 1964). Since degradation of DNA does not appear to occur rapidly, it will be assumed that exogenous DNA can function transiently while in recipients. Perhaps exogenous DNA can also become rarely and randomly rescued by the same mechanism through which residual recombination occurs in recombination deficient Escherichia coli (Clark \& Marguiles, 1965) or $\phi \times 174$ phage which are growing within recombination deficient Escherichia coli (Tessman, I966); (d) Recipient organisms are permitted to survive and grow to a greater extent on streptomycin agar plates as a result of the prior functioning of str-r DNA; $(e)$ The outcome of the sequence of postulated events is that recipients of str-r DNA would show a greater frequency of str- $r$ spontaneous mutants than control cultures since they undergo greater residual growth under selective conditions.

In this fashion a large part, or all, of the 2-4-fold excess of observed str- $r$ colonies resulting from str-r DNA treatment of recipients could be due to transitory functional transformation, and not due to genetic integration of str-r DNA into str-s genophores. It is also possible that a fraction of the str-r 'transformants' was the result of the random and rare marker rescue of str- $r$ DNA.

Consistent with these possibilities are the results obtained from u.v.-inactivation studies, by which it was shown that Mycoplasma laidlawii lacked a caffeine-inhibitable dark reactivation mechanism. From these data one could infer that $M$. laidlawii is similar to recombination-deficient u.v.-sensitive mutants of Escherichia coli K-I2 which specifically lack a recombination mechanism. The model presented above views $M$. laidlawii as a natural case of a recombination-deficient organism and resolves the results of experiments upon DNA binding, transformation, and u.v. inactivation. Other preliminary experiments have been made in this laboratory in which $M$. hominis H-39, $M$. gallisepticum, and $M$. laidlawii в have been examined for caffeine-inhibitable dark repair mechanisms. To date, these species resemble $M$. laidlawii A and appear not to possess this type of u.v. dark repair system. In an attempt to select for a variant of $M$. laidlawii A which did possess a u.v. dark repair system, survivors of 3 cyc. of 60 sec. u.v.-irradiation were isolated, but showed no difference from the parental strain as regards dark repair.

To Professor H. J. Morowitz, for critical redaction of this manuscript and for illuminating discussions, and to Jo Folsome, who performed most of the technical work, the author expresses his gratitude. This work was supported by research grant GB-4IO8 of the National Science Foundation. 


\section{REFERENCES}

Barnhart, B. J. \& Herriott, R. M. (I963). Penetration of DNA into Hemophilus influenzae. Biochim. biophys. Acta 76, 25.

CAIRNs, J. (1963). The bacterial chromosome and its manner of replication as seen by autoradiography. J. molec. Biol. 6, 208.

Clark, A. J. \& MARGULIES, A. D. (1965). Isolation and characterization of recombination deficient mutants of Escherichia coli K-1 2. Proc. natn. Acad. Sci., U.S.A. 53, 45I.

Doty, P., Marmur, J., Eigner, J. \& Schildkraut, C. (I960). Strand separation and specific recombination in deoxyribonucleic acids: physical chemical studies. Proc. natn. Acad. Sci., U.S.A. 46, 461 .

DULBECCO, R. (1950). Experiments on photoreactivation of bacteriophages inactivated with ultraviolet radiation. J. Bact. 59, 329.

EvaNs, A. (1964). Introduction of specific drug resistance properties by purified RNA-containing fractions from pneumococcus. Proc. natn. Acad. Sci., U.S.A. 52, 1142.

Folsome, C. E. (1964). Functional transformation in mammalian cell culture systems. Nature, Lond. 202, 1023.

FolsOME, C. E. \& FOLSOME, J. (I966). Temperature-sensitive conditional lethal mutants of Mycoplasma laidlawii A. Bact. Proc. p. 30.

Howard-Flanders, P. \& THERIOT, L. (I966). Mutants of E. coli K-I 2 defective in DNA repair and genetic recombination. Genetics 53 , I 137 .

MARMUR, J. (I96I). A procedure for the isolation of DNA from micro-organisms. J. molec. Biol. 3, 208.

MetzGer, K. (1964). On the dark reactivation mechanism in ultraviolet irradiated bacteria. Biochem. biophys. Res. Commun. 15, I0I.

Postel, E. H. \& GoODGAL, S. H. (1966). Uptake of single-stranded DNA in Hemophilus influenzae and its ability to transform. J. molec. Biol. 16, 317.

RAZIN, S. \& COHEN, A. (1963). Nutritional requirements and metabolism of Mycoplasma laidlawii. J. gen. Microbiol. 30, I4I.

SAUERBIER, W.(I964). Host cell reactivation of ox 174 at intracellular UV irradiation.Z. Vererbungslehre 95, 145 .

STRELZOFF, E. (1962). DNA synthesis and induced mutation in the presence of 5 -bromouracil. $Z$. Vererbungslehre $93,287$.

Tessman, I. (1966). Genetic recombination of phage $S_{13}$ in a recombination deficient mutant of E. coli K-I 2. Biochem. biophys. Res. Commun. 22, I69.

Tourtellotte, M. E., Morowitz, H. J. \& Kasimer, P. (1964). Defined medium for Mycoplasma laidlawii. J. Bact. 88, II. 